\title{
Metaphorical "networks" and verbal communication: A semiotic perspective of human discourse
}

\author{
Marcel Danesi \\ Semiotics and Communication Theory, Victoria College, University of Toronto \\ 73 Queen's Park Crescent East, Toronto, Ontario, Canada \\ e-mail: marcel.danesi@utoronto.ca
}

\begin{abstract}
This paper presents the notion that verbal discourse is structured, in form and contents, by metaphorical reasoning. It discusses the concept of "metaphorical network" as a framework for relating the parts of a speech act to each other, since such an act seems to cohere into a meaningful text on the basis of "domains" that deliver common concepts. The basic finding of several research projects on this concept suggest that source domains allow speakers to derive sense from a verbal interaction because they interconnect the topic of discussion to culturally-meaningful images and ideas. This suggests, in turn, that language is intertwined with nonverbal systems of meaning, reflecting them in the contents of verbal messages. Overall, the concept of metaphorical networks implies that human cognition is highly associative in structure.
\end{abstract}

\section{Introduction}

Verbal communication unfolds so automatically that we hardly ever take notice of the complex conceptual system that makes it possible for us to engage in it so effortlessly. In the late 1940s, the relation between that system and the grammatical system that allows us to transmit information "linearly" in actual speech situations came to constitute a central preoccupation of language and communication scientists. It was the American engineer Claude Shannon (1948) who argued in that era that information of any kind could be described in terms of binary choices between equally probable alternatives. From Shannon's work - and that of mathematician Norbert Wiener (1949), 
who pioneered the field of cybernetics and the development of computer science - there emerged a widespread notion in the language and communication sciences in the $1950 \mathrm{~s}$, which is still prevalent today, that verbal communication was subject to the same rulegoverned stochastic processes that characterize mechanical and animal signaling systems. By the 1960 s, this led to the development of theories of language, which continue, to this day, to portray language as a grammatical "object" based on universal stochastic principles. But by the 1980s, and certainly by the 1990s, it became obvious that such an approach to language hardly told the whole story of how grammar delivers concepts in even the most simple speech acts (Emmeche 2000; Kull 2000; Brier 2000). Isolated from speech, grammatical systems can indeed be described in mathematical terms, as these theories have aptly shown. But this tells us nothing about the ways in which the architecture of grammar delivers the complex meanings of sentences. Despite substantial and noteworthy research on the nature of grammatical rules and syntactic systems since the publication of Noam Chomsky's Syntactic Structures in 1957, current grammatical theories and models seem incapable of adequately explaining the conceptual richness of even the simplest of sentences. This is, no doubt, the reason why Chomsky continues to separate grammatical phenomena from meaning considerations (Chomsky 2000).

Starting in the 1970 s, there emerged several interesting attempts to make grammatical theories more sensitive to the conceptual complexity inherent in speech acts (e.g., Hymes 1971; Halliday 1975; 1985). This led to much significant work in the 1980s and 1990s examining the relation between conceptual and grammatical structure from a non-stochastic viewpoint (e.g., Fauconnier 1985; 1997; Langacker 1987; 1990; Croft 1991; Ruwet 1991; Deane 1992; Taylor 1995; Fauconnier, Sweetser 1996; Nuyts, Pederson 1997; Allwood, Gärdenfors 1998; Dirven, Verspoor 1998). The proposal put forward here is in line with such research. Indeed, my objective is to suggest that the categories making up sentence structure in discourse situations are, in effect, "reflexes" of largely unconscious "conceptual networks", whose various "circuits" are converted into specific types of words and phrases in the delivery of speech. The point of departure for such research can be traced to 1977, when Pollio, Barlow, Fine, and Pollio published their extensive investigation of common discourse texts, finding them to be structured primarily by metapho- 
rical concepts. They discovered that speakers of English, for instance, uttered on average 3,000 novel metaphors and 7,000 idioms per week. Their pivotal study was followed by Lakoff and Johnson's momentous 1980 study, Metaphors We Live By, which has since provided a powerful framework for relating the meaning of specific grammatical devices to particular conceptual structures (see, for instance, Kövecses 1986; 1988; 1990; Lakoff 1987; Johnson 1987; Sweetser 1990; Indurkhya 1992; Danesi 1993; Gibbs 1994; Goatley 1997; Lakoff, Johnson 1999). To put it in strictly semiotic terms, this line of inquiry has finally started to show how signifieds, the units of meaning and reference, can be linked etiologically to their signifiers, the physical forms that deliver these units.

Although semioticians have, by and large, been openly critical of the Chomskyan view of language (Sebeok, Danesi 2000), they have not normally become involved in research designed to provide a viable alternative based on the relation between signifieds and signifiers in language structure. The purpose of the present paper is to offer such an alternative, derived primarily from experimental and pedagogical work with second language learners - individuals who, more than anyone else, are faced with the complex task of learning how the signifiers of the new language overlap with native language signifieds and how they deliver conceptually new and/or subtly different signifieds (Danesi 2000). The claim to be made here is that verbal discourse involves a "reflexive loop" between the grammatical and the conceptual domains.

\section{Semiotic network theory}

Called langue by Saussure (1916) and linguistic competence by Chomsky (1957), knowledge of language as a rule-governed system has been traditionally assumed to be independent of how it is applied to real-life communicative situations, which Saussure called parole. In the early 1970s, the linguist Dell Hymes (1972) challenged this view, proposing that knowledge of language structure was interconnected with knowledge of how to use it appropriately in specific social settings. He called this type of knowledge communicative competence. In actual fact, the study of communicative competence was implicit in the work of various structuralist linguists and communication theorists before Hymes (e.g., Firth 1957; Jakobson 1960; Austin 1962; Dance 
1967; Searle 1969; Andersch et al. 1969; Barnlund 1970). It has become a major focus for both sociolinguistics and communication theory ever since (e.g., Myers, Myers 1985; Cherwitz, Hikins 1986; Tannen 1989; Fairclough 1995; van Dijk 1997). At the core of this approach to discourse is the idea of transaction - the view that verbal structures in discourse are "negotiated" between the interlocutors and that acts of negotiation influence cumulatively the actual grammar and vocabulary of a language. Such research has shown rather convincingly that communication variables are primary factors in modifying grammar and vocabulary, thus largely rebutting the view that grammatical systems are based on "universal properties" and thus are impervious to the influence of communication. As Colin Cherry aptly put it in his monumental study of communication, the use of language among humans "is essentially a social affair" (Cherry 1957: 9). But, with few exceptions (e.g., Kress 1985; Ellis, McClintock 1990; GarzaCuarón 1991; Cobley 1996; Agha 1997; Kramsch 1998), lacking from communicative competence theory is the fundamental semiotic view of language as a representational device interconnected with the other (nonverbal) representational systems of a culture (Verschueren 1995; Yabuuchi 1996; Edwards 1997; Danesi, Perron 1999; Jaworski, Coupland 2000). This view emphasizes that language is not an autonomous code, separate from the other codes humans employ to represent and communicate information, ideas, emotions, etc. The central notion of what I have elsewhere called semiotic network theory (Danesi 2000) is that there exist three main types of conceptual networks that link language with nonverbal codes - denotative, connotative, and metaphorical. These are reflected in the forms that specific signifiers in each of the codes of a culture assume. In short, the same signifieds surface in the form of different verbal and nonverbal signifiers because these are interconnected to each other by the same complex cognitive circuitry that characterizes the conceptual network systems present in a culture.

Network theory has been developed primarily from several research projects carried out at both the University of Toronto and the University of Lugano during the academic years 1997-1998. Over 500 students were instructed to draw up network analyses of over 200 common concepts, ranging from colors to emotions in English and Italian. Their analyses were then matched against the conceptual structures inherent in common written texts, such as newspaper and magazine articles published in Toronto and Lugano. The findings 
suggest rather strongly that verbal communication is shaped by a complex web of denotative, connotative, and metaphorical circuits that are concealed in every word, phrase, and sentence (Danesi 2000).

In Saussurean semiotics, the term concept designates the conventional meaning we get from a sign (Saussure 1916). As it turns out, however, it is not a straightforward matter to explicate what a concept is by using other words to do so. Consider, for example, what happens when we look up the definition of a word such as cat in a dictionary. Typically, the latter defines a cat as "a carnivorous mammal (Felis catus) domesticated since early times as a catcher of rats and mice and as a pet and existing in several distinctive breeds and varieties". The problem with this definition is that it uses mammal to define cat. What is a mammal? The dictionary defines mammal as "any of various warm-blooded vertebrate animals of the class Mammalia". What is an animal? The dictionary goes on to define an animal as "a living organism other than a plant or a bacterium". What is an organism? An organism, the dictionary stipulates, is "an individual animal or plant having diverse organs and parts that function together as a whole to maintain life and its activities". But, then, what is life? Life, it specifies, is "the property that distinguishes living organisms". At that point it is apparent that the dictionary has gone into a conceptual loop - it has employed an already-used concept, organism, to define life.

Looping is caused by the fact that dictionaries employ words, which of course encode other concepts, to define an entry. As it turns out, the dictionary approach just described is the only possible one for the reason that all human systems of knowledge have a looping associative structure, including mathematics, as the brilliant mathematician Kurt Gödel demonstrated in 1931. This suggests that the meaning of something can only be inferred by relating it to the meaning of something else to which it is, or can be, associated. There simply is no such thing as an "absolute concept." So, the meaning of cat is something that can only be extrapolated from the circuitry of conceptual associations that it evokes. This circuitry can be called a network. In addition to the concepts of mammal, animal, organism, and life, used by the dictionary, one can add others such as whiskers and tail to the circuitry of the cat network. In sum, the meaning of a concept such as cat crystallizes from an intricate interplay of related conceptual associations that it evokes. 
There are several things about networks and network theory that must be made clear from the very outset. First, the term theory is not used in its strictly scientific sense, but rather in its original etymological sense of "a view." Network theory is not a "theory of concepts" in the psychological sense. It simply provides a descriptive apparatus for literally showing what dictionary makers have known for centuries - namely that the meaning of something is impossible to pin down without reference to other meanings. The position of nodes (concepts), the configuration of circuits (the associations among concepts), and the "distances" between nodes and circuits in a network reflect no necessary pattern or intrinsic structure. There is no limit (maximum or minimum) to the number and types of nodes and circuits that can be used to characterize a concept. It depends on a host of factors, not the least of which is the knowledge of the networkmaker. In the network for cat, secondary circuits generated by mammal, for example, could be extended to contain carnivorous, rodent-eater, etc.; the life node could be extended to generate a secondary circuit of its own containing nodes such as animate, breath, existence, etc. in no particular order; other nodes such as feline, carnivorous, Siamese, tabby, etc. could be inserted to give a more detailed "picture" of the conceptual structure of cat; and so on. Finally, network design will vary according to case and necessity. The network described above would put cat at its focal point because that is the concept under consideration by the dictionary. However, if animal were to be needed as the focal concept, then cat would be represented differently as a nonfocal node connected to it in a circuit that would also include dog and horse, among other associated nodes. In effect, there is no way to predict the configuration of a network in advance. It all depends on the analyst, on the purpose of the analysis, on the type of concept, and on other such factors that are variable and/or unpredictable.

The primary node concepts - mammal, animal, life, and organism - are superordinate ones; cat is a basic concept; and whiskers and tail are subordinate concepts. In prototype theory (e.g., Rosch 1973), superordinate concepts are those that have a highly general referential function. Basic concepts have a typological function. They allow for reference to types of things. Finally, subordinate concepts have a detailing function. Although it is beyond the purpose of the present discussion, it would be interesting to investigate the relation of nodes and circuits (primary, secondary, etc.) to these functions and 
determine if a pattern emerges. That is something that will have to be left for future work on semiotic network analysis. Clearly, the configuration of a network will vary according to the function of its focal node - i.e. a network that has a superordinate focal node (e.g., mammal) will display a different pattern of circuitry than will one that has a basic concept at its focal center.

\section{Types of networks}

Denotative, connotative, and metaphorical concepts are not to be considered separate phenomena, but rather, interconnected to each other through various kinds of circuitry and network linkages. Denotation is the initial meaning captured by a concept. The denotative meaning of the word blue in English, for instance, encodes the image of a hue on the color spectrum with a wavelength of approximately 450 to 490 nanometers. The specific image that comes to mind will be different from individual to individual. But all images will fall within the above wavelength, if one is a native speaker of English. The denotative concept of "blueness" is forged cognitively from the experience of observing the hues found in natural phenomena such as the sky and the sea, by observing other hues in things, and so on.

The denotative network for this focal node will thus contain circuits made up of nonfocal nodes such as color, shade, hue, gradation, sky, and sea, among others. Since blue is a type of color, it is really part of a conceptual, or network, domain that has color as its focal point. However, in specific network analyses, it is not necessary to show the relevant network domain — in which blue would, in effect, be configured as a primary node connected to color. A network domain can be defined as the associative configuration generated by superordinate categories - color, animals, etc. Within such domains, basic and subordinate concepts can be subdivided, for the purpose of a specific analysis, into smaller networks of their own. That applies to the network designed for blue as a type of color interconnected to yellow, green, etc. within the same circuit.

Denotative networks allow speakers of a language to talk and think about concrete things in specific ways. But such networks are rather limited when it comes to serving the need of describing abstractions, emotions, morals, etc. For this reason they are extended considerably 
through further associative thinking. Consider the use of cat and blue in sentences such as the following ones:

(1) He's a real cool cat.

(2) Today I've got the blues.

(3) She let the cat out of the bag.

(4) That hit me right out of the blue.

These encode connotative and metaphorical meanings, which are "added" or "extended" meanings of the two concepts. The use of cat in (1) to mean "attractive," "engaging," etc. comes out of the network domain associated with jazz music; and the use of blues in (2) to mean "sad," "gloomy," etc. comes out of the network domain associated with blues music. In effect, these have been linked to the original networks of cat and blue through the channel of specific cultural traditions. They are nodes that interconnect cat and blue to the network domains of jazz and blues music.

The meaning of "something secret" associated with cat in example (3) above and the meaning of "unexpectedness" associated with blue in (4) have resulted from linking cat with the secrecy network domain and blue with the sky domain. Sentence (3) is, in effect, a specific instantiation of the conceptual metaphor [animals reflect human life and activities], which underlies common expressions such as:

(5) It's a dog's life.

(6) Your life is a cat's cradle.

(7) I heard it from the horse's mouth.

Sentence (4) is an instantiation of the conceptual metaphor [Nature is a portent of destiny] - which literary critics classify as a stylistic technique under the rubric of pathetic fallacy. This concept underlies such common expressions as:

(8) I heard it from an angry wind.

(9) Cruel clouds are gathering over your life.

The networks that are generated by metaphorical signifieds extend the meanings of signs within networks considerably. Comprehensive network analyses of cat and blue would have to show how all meanings - denotative, connotative, metaphorical — are inter- 
connected to each other through complex circuitry. It is the ability to navigate through the overarching circuitry of such networks, choosing appropriate denotative, connotative, or metaphorical nodes according to communicative need, and integrating them cohesively into appropriate individually-fashioned circuitry to match the need, that constitutes what may be called conceptual competence in a language, as opposed to abstract linguistic competence.

The connotative extensional process is, needless to say, highly associative. But it is not one based on association-by-sense, as it is in the formation of denotative concepts. Rather, it is based on association-by-inference. To grasp what this means, consider the word tail, which the dictionary defines as "the flexible appendage found at the rear end of an animal's body". This is the denotative meaning of tail in utterances such as the following:

(10) My cat's tail is over one foot long.

(11) Are there any species of dogs without tails?

(12) That horse's tail is rather short, isn't it?

In a denotative network tail, as a focal node, would be connected to a circuit that contains appendage and rear-end nodes. These provide basic information about what a tail is - an extremity - and where it is found on an animal - on its rear end. Now, these nodes are what guide the extension of tail to encompass meanings such as following:

(13) The tail of that shirt is not bleached.

(14) Do you want heads or tails for this coin toss?

(15) The tail section of that airplane is making a funny noise.

Such extensions are hardly random or disconnected to the original circuit. Shirts, coins, and airplanes are conceptualized in Englishspeaking cultures as having appendages and rear ends. In network terms, a shirt, a coin, and an airplane are concepts that belong to separate networks of their own. However, through associative inference these are interlinked to the tail network. The process of network linking can be called grafting. Grafting is the process that underlies connotation and metaphorization.

As another practical example, consider the following metaphorical statement: "The professor is a snake." Clearly, it is not the denotative meaning of the vehicle, snake, that is transferred to the topic, 
professor, but rather its connotative meanings, namely the culturespecific characteristics perceived in snakes — "slyness," "danger," "slipperiness," etc. It is this circuit of connotations linked to snake that are grafted onto the professor circuit. The grafting of the connotative nodes associated with the source network domain circuit (snake) onto the focal target domain node (professor) is what creates the meaning (or ground) of the metaphor. The concept of grafting suggests that this statement is hardly an isolated example of metaphorical fancy; rather, it implies that it is one of an infinitude of similar expressions that cluster around the idea that [human personality] is understandable in terms of [animal features]:

(16) John is a pig.

(17) That woman is a tiger.

(18) My friend is a gorilla.

(19) She roars when she gets angry.

Each is a specific instantiation of that very idea - namely [human personality is understandable in terms of animal features], or simply [people are animals]. This is dubbed a conceptual metaphor by Lakoff and Johnson (1980) and, more recently, a metaform by Sebeok and Danesi (2000). Note again that the grafting of meanings in the metaphorization process is not based on linking denotative circuits, but connotative ones. Thus, it is not the reptilian physical qualities of snakes, or the feline qualities of tigers, that are grafted onto [people], but rather the kinds of behavioral characteristics that snakes and tigers are thought to have in human terms. This is what creates the meaningful circuitry in metaphorization. It is not a simple transferal process, but one based on association-by-inference, as it has been called above. Using electric current as an analogy, it can be said that such circuits run on "alternating conceptual current," so to speak.

Given the controversy surrounding the term association in psychology and linguistics, it is necessary to clarify, albeit briefly, what is meant by it in the framework of network theory. In psychology, associationism is the theory that the mind comes to know concepts by combining simple, irreducible elements through mental connection. As is well known, interest in associationism was kindled in antiquity by Aristotle, who recognized four strategies by which associations are forged: through similarity (e.g. an orange and a lemon), through difference (e.g. hot and cold), through contiguity in time (e.g. sunrise 
and a rooster's crow), and through contiguity in space (e.g. a cup and saucer). British empiricist philosophers John Locke and David Hume saw sensory perception as the underlying factor in such processes. In the nineteenth century, the Aristotelian view was examined empirically, leading eventually to the foundation of an associationist school of psychology, guided by the principles enunciated by James Mill in his Analysis of the Phenomena of the Human Mind (1829). In addition to Aristotle's original four strategies, that school found that such factors as intensity, inseparability, and repetition added to the strength of an association: e.g. arms are associated with bodies because they are inseparable from them; rainbows are associated with rain because of repeated observations of the two as co-occurring phenomena; etc.

The one who developed associationism experimentally was Edward Thorndike, who extended the work initiated by the Russian psychologist Ivan Pavlov in 1904. Pavlov provided an empirical basis for investigating how associations through repetition are made. When he presented a meat stimulus to a hungry dog, for instance, the animal would salivate spontaneously, as expected. This was termed the dog's "unconditioned response." After Pavlov rang a bell while presenting the meat stimulus a number of times, he found that the dog would eventually salivate only to the ringing bell, without the meat stimulus. Clearly, Pavlov suggested, the ringing by itself, which would not have triggered the salivation initially, had brought about a "conditioned response" in the dog. By association the dog had learned something new. Every major behavioral psychologist has utilized the Pavlovian notion of associationism in one way or other. Although behaviorists believe all thought processes can be accounted for through associations of stimuli and responses, other psychologists strongly reject such an approach as inadequate to explain creative thought and verbal behavior.

The meaning of association as used in the network theory framework is not the Pavlovian one. In line with twentieth century Gestalt psychology, it is used to stress that abstract concepts beget their meanings only in relation to other concepts. Gestalt psychologists believed that pattern, or form, was the most important part of experience. The whole pattern in a conceptual network, for instance, gives meaning to each individual element (node, circuit, etc.) within it. In other words, the whole is more important than the sum of its parts. As discussed above, network patterns can be forged by sense, i.e. by 
observing physical features of referents, or by inference, i.e. by applying the sense associations to referents that are perceived as possessing the same features.

\section{Reflexivization}

Associative conceptual structure is converted into linear surface grammatical structure through a process that can be called reflexivization. Consider, for example, an underlying circuit containing snake as a metaphorical concept that is to be used in a specific speech act. In the surface language that is chosen to deliver it, it can show up as a verb (20), if it is the snake's movements that are grafted onto the target, or as an adjective (21), if it is a serpentine quality that is grafted conceptually onto the target:

(20) The professor snaked his way around the issue.

(21) The professor has a snaky way of doing things.

The difference between the two surface forms - snaked and snaky can be traced to underlying circuits that extend the snake concept in specific ways. The reflexivization of (20) shows that the grafted concept included a movement node. In (22) the relevant circuit grafted onto the target concept included, instead, a quality node.

The notion of reflexivization is not a theory of grammar. It is a heuristic technique for showing how words, phrases, and sentences appear to reflect conceptual structure, i.e. to encode it in specific ways. Needless to say, surface linear structure reflects not only concepts, but is also sensitive to communicative functions, situational variables, stylistic needs, etc. There are an infinitude of ways in which the reflexivization of concepts can unfold. The choices made by the speaker, the context of the speech act, the grammatical and lexical knowledge of the speaker, etc. are the factors that constrain surface structure outcomes. It is not the purpose of reflexivization analysis to consider these factors. The main objective of such analysis is showing how grammar, vocabulary, and concepts are interconnected in a systemic way.

Differences in surface linear structure are typically due to underlying conceptual dichotomies. In Italian, for instance, the difference between the denotative and connotative meaning of an adjectival 
concept is sometimes reflected in the surface by a difference in position with respect to the noun. Thus, in (22) and (23), the different surface position of the adjective is a reflex of the different networks to which the meanings belong:

(22) Lui è un uomo povero ("He's an indigent man").

(23) Lui è un povero uomo ("He's a forlorn man").

In (22) it is the denotative meaning of povero that is reflected in the surface by a post-positioning of the adjective with respect to the noun (the normal position for qualitative adjectives). In (23) the connotative meaning of povero is indicated by means of its pre-positioning, alerting the interlocutor in an anticipatory fashion as to the type of concept that is intended.

As another example of how conceptual dichotomies are reflexivized, consider the use of the English prepositions since and for in sentences such as the following:

(24) I have been living here since 1980.

(25) I have known Lucy since November.

(26) I have not been able to sleep since Monday.

(27) I have been living here for twenty years.

(28) I have known Lucy for nine months.

(29) I have not been able to sleep for seven days.

An analysis of the complements that follow since or for reveals that those that follow the former are [points in time], i.e. they are complements that reflect a conception of time as a [point] on a [timeline] which shows specific years, months, etc.: 1980, November, Monday, etc. Complements that follow for, on the other hand, reflect a conception of time as a [quantity]: twenty years, nine months, seven days, etc. These two network domains - [time is a point] and [time is a quantity] - have an underlying metaphorical circuitry structure, reflecting our propensity to imagine an abstract notion such as "time" in terms of something concrete. These can now be seen to have a specific effect at the level of syntax by motivating a grammatical dichotomy - complements introduced by since are reflexes of the conceptual domain [time is a point]; those introduced by for are reflexes of the conceptual domain [time is a quantity]. This is, in fact, the kind of rule of grammar that reveals how concepts are encoded 
linearly - it relates, in effect, how two specific domains of conceptualization have worked their way into the grammar. In a word, this rule stipulates how a grammatical dichotomy reflects a conceptual dichotomy.

Take, as one final example, the selection of certain verbs in particular types of sentences in Italian. The verb fare "to make" is used to convey a weather situation - fa caldo (literally) "it makes hot," fa freddo (literally) "it makes cold." The physical states of [hotness] and [coldness] are conveyed instead by the verb essere "to be" when referring to objects - è caldo "it is hot," $\grave{e}$ freddo "it is cold" - and by avere "to have" when referring to people — ha caldo "he/she is hot," ha freddo "he/she is cold." The use of one verb or the other-fare, essere, or avere - is motivated by an underlying metaphorical conceptualization of bodies and the environment as [containers]. So, the [containment context] in which the quality of [hotness] or [coldness] is located determines the verbal category to be employed. If it is in the environment, it is "made" by Nature ( $\mathrm{fa}$ caldo/freddo); if it is in a human being, then the body "has" it (ha caldo/freddo); and if it is in an object, then the object "is" its container (è caldo/freddo).

To summarize, it is obvious that conceptual domains leave their reflexes in the grammars of specific languages. Knowledge of such differentiated reflexive properties is what guides conceptually-appropriate communication among interlocutors. Grammar in this framework is definable, therefore, as a system that reflexivizes conceptual circuitry in specific ways.

It must be emphasized again that the notion of reflexivization is not a theory of grammar. It is proposed simply to show that in the same way that a painting is much more than an assemblage of lines, shapes, colors, and melodies a combination of notes and harmonies, so too a sentence in language is much more than an assemblage of words and phrases built from some abstract rule system in the brain. We use the surface grammatical and lexical codes at our disposal to model the world of concepts in ways that parallel how musicians use melodic elements and painters visual ones to model it. 


\section{Discourse}

Network analyses of conversations show, above all else, that discourse is structured largely by connotative inter-network linkages. A truly interesting feature of discourse that this type analysis also reveals can be called connotative chaining. This occurs when a specific connotative node generates derivative associations in the immediate span of the discourse. To put it figuratively, it tends to "infect" the whole conversation. For instance, once a word such as drop is used connotatively by a speaker in a certain situation, then it may spawn a chain of associated concepts such as pick up, let go, etc. Here is an example of a conversation excerpt that I recorded at the University of Toronto, during which a speaker (a university student) used the word drop as just described: "Yeah, I dropped that course yesterday... No, I won't pick it up next year... The main reason for letting it go was the prof. He was awful... Believe me, I haven't lost anything..."

In this sample of discourse, the connotative meaning of drop initiated a circuit on its own that included pick up, let go, and lose in close proximity to each other. In effect, the image of "falling" is distributed in the circuit, surfacing in various lexical forms. The nodes are linked again through a process of association-by-inference picking up something means that it was dropped; losing something elicits the image of dropping it; and, of course, letting something go will cause it to drop. The construction of the circuit is a subjective act, based on grafting nodes from network domains. This is what makes discourse unpredictable in actual form, but understandable, and even predictable, conceptually.

Once connotative circuits have been introduced into discourse they tend to guide the flow of conversation through chaining. In the above circuit, for instance, the pick up node led a little later in the conversation to the use of take, which, in turn, generated its own circuitry with two nodes - carry and heavy: "I really can't take any more subjects... I'm already carrying the maximum... I've got quite a heavy load..."

There are various kinds of connotative chains that characterize discourse flow. Some of these contain nodes based on narrative traditions; these are concepts referring to themes, plot-lines, characters, and settings that surface in narratives. Calling someone a Casanova or a Don Juan, rather than lady-killer, evokes an array of sociallysignificant connotations that these characters embody. Referring to a 
place as Eden or Hell elicits connotations that have a basis in mythic and religious narrative. The circuits that have been grafted from these stories also surface constantly in common discourse events. Climatologists, for example, refer to the warming of the ocean surface off the western coast of South America that occurs every 4 to 12 years when upwelling of cold, nutrient-rich water does not occur as a person, $E l$ Niño, "the little one" in Spanish. This mythic personification of a climatological condition makes it much more understandable in human terms. Although people do not think of El Niño as a mythic figure, they nonetheless find it convenient to blame "him" for certain weather repercussions as if it were one. This is how original myths worked cognitively — the difference being that the personified conditions of the past were actually believed to be real gods or mythical beings. The discourse that surrounds El Niño is virtually always interpretable in mythic terms. For instance, I recorded a weather commentary on American television recently that contained a circuit generated by mythic personification: "This year El Niño is having a great time of it. He has wreaked havoc upon anyone or anything in his path. He has come down very strenuously upon us."

In effect, connotative and metaphorical circuitry in discourse is densely distributed through networks present in the entire system of culture. Take, as an example, the up-down metaphorical concept that entails the connotative feature [verticality]. In verbal discourse this feature is a node that is reflexivized commonly in expressions such as the following:

(30) I'm feeling up.

(31) They're feeling down

(32) I'm working my way up the ladder of success

(33) His enthusiasm has gone down considerably.

This same concept manifests itself in the religious domain, where goodness, spirituality, and heaven are portrayed as up, and evil, damnation, and hell as down in sermons, theological narratives, religious visual representations, the design of churches, etc. In public building design, too, it can be discerned in the fact that the taller office buildings in a modern city are the ones that indicate which institutions (and individuals) hold social and economic power. In musical composition, higher tones are typically employed to convey a sensation of happiness, lower ones of sadness. During speech, the 
raising of the hand designates notions of amelioration, betterment, growth, etc., whereas the lowering of the hand designates the opposite notions. In bodily representation and perception, this concept shows up in the common viewpoint that taller is more attractive/shorter is less attractive. In mathematical and scientific representational practices its reflexivization can be seen, for instance, in the ways in which graphs are designed - lines that are oriented in an upward direction indicate a growth or an increase of some kind, while those that are slanted in a downward direction indicate a decline or decrease.

The foregoing analysis of interconnected networks is intended to show how highly complementary abstractions are to each other and how they are utilized to generate representational practices and systems. The [people are animals] network discussed above is the source of such symbolic activities as the use of animals in totemic codes, in heraldic traditions, in the creation of fictional characters for use in story-telling to children (Bugs Bunny, Foghorn Leghorn, Daffy Duck, etc.), in the naming of sports teams (Chicago Bears, St. Louis Cardinals, Miami Dolphins, etc.), and in the creation of surnames, to mention but a few.

This type of analysis also explains why discourse texts produced by computers and foreign-language learners alike (at the beginning of their study of a new language) will manifest a high degree of accuracy in sentence-formation, but they will invariably lack the conceptual appropriateness that characterizes the corresponding discourse texts of native speakers. To put it another way, students and machines "speak" artificially with the formal grammatical structures of the language as they have been taught them or programmed to do respectively, but they are unable to "think" in terms of the conceptual system that underlies the structures: i.e. students typically make-up target language sentences as artificial "carriers" of their own native language concepts through the rules they have been taught; computers generate them in response to the rules programmed into them. When these coincide with the ways in which concepts are relayed by native speakers naturally, then the student and machine texts coincide serendipitously with culturally-appropriate discourse texts; when they do not, they manifest an asymmetry between sentence form and conceptual content. 


\section{Concluding remarks}

The notions of semiotic networks and of reflexivization raise some specific questions for future research. The guiding question is: What are the verbal cues that reveal conceptual domains? In this paper, for instance, the structures since and for were related to the conceptual domain as reflexes of differentiated metaphorical networks: [time is a point] and [time is a quantity]. The work on cognitive grammar by Langacker (1987; 1990), as mentioned, is leading the way in showing us how analyses of this type might be envisioned. Another question is to determine to what extent and in what ways conceptual networks relate to, or are embedded in, world knowledge. Is world knowledge built up from such circuitry? And if so, how is this incorporable into an extensive analysis of language? Some possibilities have been explored in the past (e.g., Pike 1967), and I believe that this kind of exploration is the wave of the future in semiotics, linguistics, and communication science. As Levin (1988: 10) has aptly remarked, however, one must proceed cautiously in this area of inquiry, simply because the many modes of knowing defy the possibility of envisioning a single theory - e.g., innate knowledge, personal knowledge, tacit knowledge, spiritual knowledge, declarative and procedural knowledge, knowing that and knowing how, certitude (as well as certainty), and so on. The more appropriate goal for linguistics and semiotics should be, therefore, to determine to what extent and in what specific ways language reflects knowledge structures.

The bulk of the work on grammatical systems in linguistics and verbal communication generally has traditionally excluded the relation between concepts and grammatical categories. The present study has aimed to show, however, that sentence form is shaped by conceptual factors much more than traditional grammatical analysis would allow. The effect of conceptual structure on categorization in grammar has been taken up somewhat in the linguistic literature, but it has never really penetrated the mindset of language scientists until recently. The philosopher Herder, for instance, saw an intimate connection between language and what he called "ethnic character." Subsequently, Wilhelm von Humboldt gave Herder's hypothesis a more testable formulation when he portrayed the structure of a particular language as interdependent with the thought and behavior of the people using it for communication. Needless to say, von Humboldt's perspective went contrary to the views of the Port-Royale grammarians who saw 
language as the product of the universal logical laws of the human mind. It was shortly after von Humboldt's alluring pronouncements that the study of "language and mind" was given its first scientific research impetus. In the twentieth century, work on language and thought was pursued by both those espousing a Humboldtian perspective - Sapir (1921), Whorf (1956), and others - and those advocating a universalist Port Royale perspective - especially Chomsky. As mentioned, the goal of Humboldtians, such as Sapir and Whorf, has never been truly envisioned by mainstream linguistics until very recently. The North American version of linguistic science took its characteristic shape and methodological orientation from Leonard Bloomfield's 1933 textbook entitled simply Language. In the same way that Euclid's Elements bestowed systematicity and unity upon the study and practice of geometry in antiquity through its coherent synthesis of geometrical concepts and techniques, so too did Language provide the fledgling science of linguistics in the 1930s with an organized repertory of notions and procedures for carrying out detailed investigations and analytical characterizations of specific languages. This is the main reason why, in my view, Bloomfield's Language, and not the work bearing the same title and published more than a decade earlier by Edward Sapir (1921), came to be accepted by the majority of linguists as the point of reference for conducting empirical research and for developing models of language design.

While Bloomfield's work constituted the first true "textbook" in the history of linguistic science, Sapir's book was the first real attempt to provide a framework for studying the relation of language to cognition and culture. And whereas for most of the twentieth century linguists diligently pursued the investigation of language systems per se, along the lines laid down first by Bloomfield and later by Chomsky, they have recently started to move more and more toward the adoption of Sapir's original paradigm.

The question that Sapir sought to answer throughout his life is probably as old as civilization itself: How is thought related to language? He was intrigued, in other words, by the possibility that human ideas, concepts, feelings and characteristic social behaviors might be mirrored by the verbal categories that specific cultures employ to codify them. Sapir suspected that the most direct route to the mind was through language. Due to his tragically early death, Sapir was never able to design and carry out a research program aimed at examining his idea rigorously and systematically. As is well known, 
it fell on the shoulders of Sapir's brilliant student Benjamin Lee Whorf (1956) to elaborate substantively upon his mentor's views and to give them a more empirically-testable articulation. Whorf posited, in essence, that the categories of one's particular language are much more than simple mediators of thought. He saw them as being the "shapers" of the very thought patterns they embody: "The world is presented in a kaleidoscopic flux of impressions which has to be organized by our minds - and this means largely by the linguistic systems in our minds" (Whorf 1956: 153). But Whorf's experimental program for studying the language-thought nexus could not have been devised without his teacher's profound insights. Sapir saw language as being much more than a communication system. He considered it to be a kind of cognitive filter through which humans come to perceive and understand the world around them.

Semiotic network theory is an attempt to make good on Sapir's agenda for linguistic science. It is just one way that can be envisaged for relating formally how thought and language are interdependent. Grammatical properties cannot be studied in isolation. To rewrite natural grammars with reflexive rules would imply research on the domains of meaning that are implicit in sentences first and, then, to connect the grammatical categories to these in direct ways. Some of the ways have been discussed tentatively in this paper. There is no doubt that future work in semiotics and linguistics will show how to encompass all the traditional morphological and syntactic categories within a semiotic framework of meaning. Within this framework, everything form verb tenses to adverb usage will be linked to the interconnected experiences of the world that are manifested in the use of a language by native speakers in cultural contexts. This was the research challenge put forward by Sapir; and the time has come to take up his challenge seriously.

\section{References}

Agha, Asif 1997. Concept and communication in evolutionary terms. Semiotica 116: 189-215.

Allwood, Jens; Gärdenfors, Peter (eds.) 1998. Cognitive Semantics: Meaning and Cognition. Amsterdam: John Benjamins.

Andersch, Elizabeth G.; Staats, Lorin C.; Bostrom, Robert N. 1969. Communication in Everyday Use. New York: Holt, Rinehart \& Winston. 
Austin, John Langshaw 1962. How to Do Things with Words. Cambridge: Harvard University Press.

Barnlund, Dean C. 1970. A transactional model of communication. In: Sereno, Kenneth K.; Mortensen, C. David (eds.), Foundations of Communication Theory. New York: Harper \& Row, 83-102.

Bloomfield, Leonard 1933. Language. New York: Holt.

Brier, Søren 2000. Biosemiotics as a possible bridge between embodiment in cognitive semantics and the motivation concept of animal cognition in ethology. Cybernetics and Human Knowing 7: 57-76.

Cherry, Colin 1957. On Human Communication. Cambridge: MIT Press.

Cherwitz, Richard A.; Hikins, James W. 1986. Communication and Knowledge: An Investigation in Rhetorical Epistemology. Columbia: University of South Carolina Press.

Chomsky, Noam 1957. Syntactic Structures. The Hague: Mouton.

- 2000. New Horizons in the Study of Language and Mind. Cambridge: Cambridge University Press.

Cobley, Paul (ed.) 1996. The Communication Theory Reader. London: Routledge.

Croft, William 1991. Syntactic Categories and Grammatical Relations. Chicago: University of Chicago Press.

Dance, Frank 1967. Human Communication Theory. New York: Holt, Rinehart \& Winston.

Danesi, Marcel 1993. Vico, Metaphor, and the Origin of Language. Bloomington: Indiana University Press.

- 2000. Semiotics in Language Education. Berlin: Mouton de Gruyter.

Danesi, Marcel; Perron, Paul 1999. Analyzing Cultures: A Handbook and Reference Manual. Bloomington: Indiana University Press.

Deane, Paul D. 1992. Grammar in Mind and Brain: Explorations in Cognitive Syntax. Berlin: Mouton de Gruyter.

Dijk, Teun A. van (ed.) 1997. Discourse as Social Interaction. London: Sage.

Dirven, René; Verspoor, Marjolijn 1998. Cognitive Exploration of Language and Linguistics. Amsterdam: John Benjamins.

Edwards, Derek 1997. Discourse and Cognition. London: Sage.

Ellis, Richard; McClintock, Ann 1990. If You Take My Meaning: Theory into Practice in Human Communication. London: Arnold.

Emmeche, Claus 1998. Defining life as a semiotic phenomenon. Cybernetics and Human Knowing 5: 33-43.

Fairclough, Norman 1995. Critical Discourse Analysis: The Critical Study of Language. London: Longman.

Fauconnier, Gilles 1985. Mental Spaces. Cambridge: Cambridge University Press.

- 1997. Mappings in Thought and Language. Cambridge: Cambridge University Press.

Fauconnier, Gilles; Sweetser, Eve (eds.) 1996. Spaces, Worlds, and Grammar. Chicago: University of Chicago Press.

Firth, John Rupert 1957. Papers in Linguistics: 1934-1951. Oxford: Oxford University Press.

Garza-Cuarón, Beatriz 1991. Connotation and Meaning. Berlin: Mouton de Gruyter. 
Gibbs, Raymond W. 1994. The Poetics of Mind: Figurative Thought, Language, and Understanding. Cambridge: Cambridge University Press.

Goatley, Andrew 1997. The Language of Metaphors. London: Routledge.

Gödel, Kurt 1931. Über formal unentscheidbare Sätze der Principia Mathematica und verwandter Systeme, Teil I. Monatshefte für Mathematik und Physik 38: 173-189.

Halliday, Michael A. K. 1975. Learning How to Mean: Explorations in the Development of Language. London: Arnold.

- 1985. Introduction to Functional Grammar. London: Arnold.

Hutchby, Ian; Wooffitt, Robin 1998. Conversation Analysis. Cambridge: Polity Press.

Hymes, Dell 1971. On Communicative Competence. Philadelphia: University of Pennsylvania Press.

Indurkhya, Bipin 1992. Metaphor and Cognition: An Interactionist Approach. Dordrecht: Kluwer.

Jakobson, Roman 1960. Closing statement: Linguistics and poetics in retrospect. In: Sebeok, Thomas A. (ed.), Style and Language. Cambridge: MIT Press, $350-377$.

Jaworski, Adam; Coupland, Nikolas (eds.) 2000. The Discourse Reader. London: Routledge.

Johnson, Mark 1987. The Body in the Mind: The Bodily Basis of Meaning, Imagination and Reason. Chicago: University of Chicago Press.

Kövecses, Zoltán 1986. Metaphors of Anger, Pride, and Love: A Lexical Approach to the Structure of Concepts. Amsterdam: John Benjamins.

- 1988. The Language of Love: The Semantics of Passion in Conversational English. London: Associated University Presses.

- 1990. Emotion Concepts. New York: Springer.

Kramsch, Claire 1998. Language and Culture. Oxford: Oxford University Press.

Kress, Gunther 1985. Linguistic Processes in Sociocultural Practice. Melbourne: Deakin University Press.

Kull, Kalevi 2000. Organisms can be proud to have been their own designers. Cybernetics and Human Knowing 7: 45-56.

Lakoff, George 1987. Women, Fire, and Dangerous Things: What Categories Reveal about the Mind. Chicago: University of Chicago Press.

Lakoff, George; Johnson, Mark 1980. Metaphors We Live By. Chicago: Chicago University Press.

Lakoff, George; Johnson, Mark 1999. Philosophy in the Flesh: The Embodied Mind and Its Challenge to Western Thought. New York: Basic.

Langacker, Ronald W. 1987. Foundations of Cognitive Grammar. Stanford: Stanford University Press.

- 1990. Concept, Image, and Symbol: The Cognitive Basis of Grammar. Berlin: Mouton de Gruyter.

Levin, Samuel R. 1988. Metaphoric Worlds. New Haven: Yale University Press.

Myers, Gail E.; Myers, Michele T. 1985. The Dynamics of Human Communication: A Laboratory Approach. New York: McGraw-Hill.

Nuyts, Jan; Pederson, Eric (eds.) 1997. Language and Conceptualization. Cambridge: Cambridge University Press. 
Pike, Kenneth 1967. Language in Relation to a Unified Theory of the Structure of Human Behavior. The Hague: Mouton.

Pollio, Howard R.; Barlow, Jack M.; Fine, Harold J.; Pollio, Marilyn R. 1977. The Poetics of Growth: Figurative Language in Psychology, Psychotherapy, and Education. Hillsdale: Lawrence Erlbaum Associates.

Rosch, Eleanor H. 1973. On the internal structure of perceptual and semantic categories. In: Moore, T. E. (ed.), Cognitive Development and Acquisition of Language. New York: Academic, 111-144.

Ruwet, Nicolas 1991. Syntax and Human Experience. Chicago: University of Chicago Press.

Saussure, Ferdinand de 1916. Cours de linguistique générale. Paris: Payot.

Searle, John R. 1969. Speech Acts: An Essay in the Philosophy of Language. Cambridge: Cambridge University Press.

Sebeok, Thomas A.; Danesi, Marcel 2000. The Forms of Meaning: Modeling Systems Theory and Semiotic Analysis. Berlin: Mouton de Gruyter.

Shannon, Claude 1948. A mathematical theory of communication. Bell Systems Technical Journal 27: 379-423.

Sweetser, Eve 1990. From Etymology to Pragmatics: The Mind-as-Body Metaphor in Semantic Structure and Semantic Change. Cambridge: Cambridge University Press.

Tannen, Deborah 1989. Talking Voices. Cambridge: Cambridge University Press.

Taylor, John R. 1995. Linguistic Categorization: Prototypes in Linguistic Theory. Oxford: Oxford University Press.

Verschueren, Jef 1995. Linguistic pragmatics and semiotics. Semiotica 104: 157170.

Wiener, Norbert 1949. Cybernetics, or Control and Communication in the Animal and the Machine. Cambridge: MIT Press.

Yabuuchi, Akio 1996. Diagramming discourse structures: Illocution, interaction, or text? Semiotica 110: 197-229.

\section{Метафорическая «сеть» и вербальная коммуникация: семиотическая перспектива человеческого дискурса}

В статье утверждается, что языковой дискурс структурирован (на уровне формы и содержания) на метафорической основе. Понятие "метафорическая сеть" используется в качестве соотносительной рамки разных частей речевого акта, так как речевые акты соединяются в осмысленный текст на основе “общностей”, которые передают общие понятия. Разные исследования, занимающиеся этим концептом, выявляют факт, что именно эти общности в качестве источников позволяют говорящему в ходе вербальной интеракции вывести значение, соединяя дискутируемую тему культурно значимыми образами и идеями. Из этого, в свою очередь, следует, что 
язык тесно переплетается с невербальными системами значения, отражая их в содержании языковых сообщений. Таким образом, понятие метафорическая сеть приводит нас к мысли, что структура человеческой когнитивной деятельности во многом ассоциативна.

\section{Metafoorilised "võrgustikud" ja verbaalne kommunikatsioon: inimdiskursuse semiootiline perspektiiv}

Artiklis väidetakse, et keeleline diskursus on struktureeritud (nii vormi kui sisu tasandil) metafoorilisel põhimõttel. Mõistet "metafooriline võrgustik" käsitletakse kui kõneakti osade suhestumisraamistikku, kuivõrd kõneaktid ühenduvad tähenduslikuks tekstiks "valdkondade" alusel, mis edastavad ühiseid mõisteid. Erinevad seda kontsepti käsitlevad uurimused toovad esile, et just allikvaldkonnad võimaldavad rääkijail tuletada tähendus verbaalses interaktsioonis, ühendades käsitletava teema kultuuriliselt tähenduslike kujundite ja ideedega. Sellest omakorda järeldub, et keel on tihedalt läbi põimunud mitteverbaalsete tähendussüsteemidega, peegeldades neid keeleliste teadete sisus. Seega, metafooriliste võrgustike mõistest tuleneb, et inimtunnetus on suurel määral assotsiatiivse struktuuriga. 